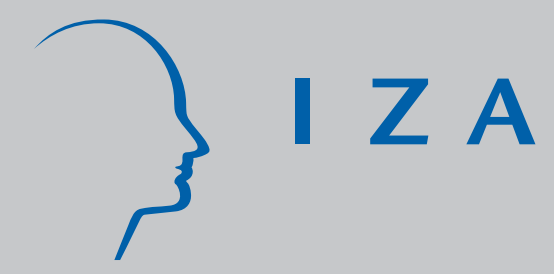

IZADP No. 1541

Returns to Computer Use and Organizational Practices of the Firm

Benoit Dostie

Mathieu Trépanier

March 2005 


\title{
Returns to Computer Use and Organizational Practices of the Firm
}

\author{
Benoit Dostie \\ HEC Montréal, CREF, CIRPÉE , CIRANO \\ and IZA Bonn \\ Mathieu Trépanier \\ Kellogg School of Management, Northwestern University
}

Discussion Paper No. 1541

March 2005

\author{
IZA \\ P.O. Box 7240 \\ 53072 Bonn \\ Germany \\ Phone: $+49-228-3894-0$ \\ Fax: +49-228-3894-180 \\ Email: iza@iza.org
}

\begin{abstract}
Any opinions expressed here are those of the author(s) and not those of the institute. Research disseminated by IZA may include views on policy, but the institute itself takes no institutional policy positions.

The Institute for the Study of Labor (IZA) in Bonn is a local and virtual international research center and a place of communication between science, politics and business. IZA is an independent nonprofit company supported by Deutsche Post World Net. The center is associated with the University of Bonn and offers a stimulating research environment through its research networks, research support, and visitors and doctoral programs. IZA engages in (i) original and internationally competitive research in all fields of labor economics, (ii) development of policy concepts, and (iii) dissemination of research results and concepts to the interested public.
\end{abstract}

IZA Discussion Papers often represent preliminary work and are circulated to encourage discussion. Citation of such a paper should account for its provisional character. A revised version may be available directly from the author. 


\section{ABSTRACT Returns to Computer Use
and Organizational Practices of the Firm*}

In this paper, we test the hypothesis that computer use will lead to productivity gains only if the firm uses an appropriate set of organizational practices. Detailed data on organizational practices and workers' compensation are obtained through a Canadian longitudinal linked employer-employee database called the Workplace and Employee Survey (WES). Linked data allow us to take into account both worker and firm unobserved heterogeneity through the estimation of a linear mixed model of wage determination. Our results suggest a small but positive computer-wage premium whose size is related to a set of organizational practices.

JEL Classification: D21, J30, J31, O33

Keywords: $\quad$ wage determination, human capital, computers, mixed models, linked employer-employee data, organizational practices of the firm

Corresponding author:

Benoit Dostie

Institute of Applied Economics

HEC Montréal, University of Montréal

Montréal (Québec), H3T 2A7

Canada

Email: benoit.dostie@hec.ca

\footnotetext{
* We thank Richard Chaykovsky, Rob Clark, Avi Goldfard, Rajshri Jayaraman, Paul Lanoie, PierreThomas Léger, Pierre-Yves Steunou and participants in the 2004 CEA and SCSE Conferences for valuable comments. We acknowledge financial support from the Social Sciences and Humanities Research Council of Canada through the Initiatives on the New Economy program. The ususal caveat applies.
} 


\section{Introduction}

In this paper, we test whether or not the use of information technology (IT) at work leads to higher productivity. In the microeconomic literature, this has been tested using two methodologies. A first strand of the literature uses wage as a measure of worker productivity and examines the link between computer use and wage gain. In a widely cited study, Krueger (1993) estimates wage equations augmented for the use of a computer at work using 1984 and 1989 U.S. microdata given by the Current Population Survey. He finds that computer use on the job is related to a 15 to $20 \%$ wage premium (depending on the specification and on the year).

In a subsequent study, DiNardo and Pischke (1997) investigate the importance of selection in explaining the results in Krueger (1993). Computer use is endogenous if firms are more likely to give computers to their most productive workers. If this is the case, Krueger's estimates of the computer-wage premium cannot be attributed to productivity gains related to the use of IT. These authors argue that the use of widely available "white collar" tools such as pencils, chairs, etc. at work does not require any special ability and should not yield a premium to workers using them. Using German data, they find that workers who use these tools earn 9 to $14 \%$ more than nonusers who are otherwise identical based on observed characteristics. They conclude that since there is an important selection effect in the use of pencils (which is what the return to the use of pencils suggests), then we should expect that selection is also important for the use of computers. If we assume that the selection effect is responsible for $9-14 \%$ of the OLS wage premium, then return for computer use should fall to about $4-7 \%$.

Entorf and Kramarz (1997) are, to our knowledge, the first to examine the computer wage premium with panel data to control for individual unobserved 
heterogeneity (ability) using person fixed effects. They find that there is only a small return to experience with the technology. In a subsequent article, Entorf, Gollac, and Kramarz (1999) show that accounting for workplace unobserved heterogeneity simultaneously with worker unobserved heterogeneity (as Abowd, Kramarz, and Margolis (1999)) does not change their earlier conclusion. The consensus in the computer-wage-premium literature appears to be that apart from a small return to experience with the technology, there is no significant return to the use of a computer ${ }^{1}$ (see for example chapter 6 in Levy and Murname (2004)).

The second strand of the literature is based on production function estimation and links some measure of firm performance to investments in new technologies ${ }^{2}$. This literature presents evidence that investments in information technology do lead to higher productivity. However, these productivity gains seem to depend on the firm's use of certain organizational practices such as team work or decentralization (Bresnahan, Brynjolfsson, and Hitt (2002)). For example, Brynjolfsson and Hitt (1995) use firm fixed effects to control for the endogeneity of information technology (IT) investments in the estimation of production functions. Their estimates show that in the U.S., from 1988 to 1992, controlling for firm unobserved heterogeneity explains as much as $50 \%$ of the productivity gains from IT investments as compared to OLS estimates, while leaving other coefficients almost unaffected. They conclude that unobserved organizational practices of the firm probably affect the return to investments in IT.

\footnotetext{
${ }^{1}$ Recent examples include Chennells and Reenen (2002), Anger and Schwarze (2003), Lee and Kim (2004) and Dolton and Makepeace (2004).

${ }^{2}$ See especially Bartel and Sicherman (1999), Berman, Bound, and Griliches (1994), Doms, Dunne, and Trostke (1997) and Autor, Katz, and Krueger (1998)). The focus of this literature (while initially about the relationship between the use of new technologies, productivity gains and relative demand for qualified workers) has recently moved to incorporate the additional impact of the firm's organizational practices (Brynjolfsson and Hitt (1995), Bertschek and Kaiser (2004), Black and Lynch (2001), Bresnahan, Brynjolfsson, and Hitt (2002), Hitt and Brynjolfsson (2002) and Brynjolfsson and Hitt (2003)).
} 
Similar results are obtain by Brynjolfsson and Hitt (2003). They examine the relationship between growth in computer investments and growth in output in the U.S. between 1987 to 1994. They find a positive relationship between the impact of lagged computer investments on output growth, the cumulative impact being stronger when earlier investments are added to the specification. Their interpretation is that short term returns are a measure of the direct effect of IT investments while longer returns give information on a combined return of both IT and organizational investments.

In another attempt to control for endogenous IT investments, Bertschek and Kaiser (2004) estimate a simultaneous equation model for the impact of IT investments and work reorganizations on German firm productivity in 2000. Firms are assumed to undergo some kind of work reorganization if the benefits of the reorganization outweight the associated costs. They find that elasticities of IT and non-IT investments are not statistically different between firms that reorganized and those that did not. However, the point estimates are generally larger with reorganization than without. Using kernel density techniques, they show that the entire distribution shifts to the right suggesting a positive relationship between workplace reorganization and labor productivity.

These results outline a gap between wage regression results and those from production function estimations. In order to reconcile these two sets of contradictory results, we use a new longitudinal Canadian linked employer-employee data set (the Workplace and Employee Survey (WES)) containing information on both wages at the worker level and organizational practices at the firm level. While the longitudinal nature of the data allows us to control for unobserved worker heterogeneity and control for self-selection in computer use, we are also able to control for both observed firm heterogeneity in organizational practices and residual unobserved firm heterogeneity. 
Controlling for unobserved firm heterogeneity is crucial if firms differ in some unobserved way that affects both labor productivity and investments decisions in new technologies. This will be the case if (1) IT is a general-purpose technology that lowers the cost of some complementary innovations, (2) firms are heterogeneous in the cost reduction they face when implementing IT and (3) firms' investments in IT depend on this unobserved heterogeneity in cost reduction (Brynjolfsson and Hitt (2002), Bresnahan and Trajtenberg (1995)). Failure to take into account this unobserved firm heterogeneity will lead to biased estimates of the returns to computer use.

However, controlling for unobserved firm heterogeneity through fixed effects (like Entorf, Gollac, and Kramarz (1999)) will not be sufficient to ensure unbiased estimates of the return to computer use if these returns are affected by time-varying firm unobserved heterogeneity. This will be the case with organizational practices if the firms investing in new technologies are simultaneously changing their organizational practices to take advantage of the new possibilities made possible by such investments.

Our least square and fixed worker effects results are similar to those found in the literature where the wage premium is estimated at $20 \%$ and $0 \%$, respectively $^{3}$. However, once we control for unobserved firm heterogeneity in addition to worker heterogeneity using a mixed model of wage determination along the lines of Abowd and Kramarz (1999b), we find significant returns to computer use of $5-6 \%$. This is different from Entorf, Gollac, and Kramarz (1999) who also control for firm unobserved heterogeneity through fixed effects and find no return to computer use ${ }^{4}$. Finally, we find evidence that returns to computer use are linked to organizational practices at the firm level in both fixed and

\footnotetext{
${ }^{3}$ See Krueger (1993) for similar OLS results and Entorf and Kramarz (1997) for similar results with individual fixed effects.

${ }^{4}$ These differences could be explained by higher computer returns in the late nineties or/and higher computer returns in North America as compared to Europe. Productivity growth differences in Europe and in the U.S. are documented in Gordon (2004).
} 
mixed-effects specifications.

In the next section, we describe our statistical model of wage determination. We then turn to our estimation strategy, data description, results and conclusion.

\section{Statistical Model}

In order to take into account both firm and workplace heterogeneity in our model of wage determination, we use a two-factor analysis of covariance with repeated observations along the lines of Abowd and Kramarz (1999b):

$$
y_{i t}=\mu+\mathbf{x}_{i t} \boldsymbol{\beta}+\theta_{i}+\psi_{j(i, t)}+\epsilon_{i t}
$$

with

$$
\theta_{i}=\alpha_{i}+\mathbf{u}_{i} \boldsymbol{\eta}
$$

where $y_{i t}$ is the $(\log )$ wage rate observed for individual $i=1, \ldots, N$, at time $t=1, \ldots, T_{i}$. Person effects are denoted by $i$, firm effects by $j$ as a function of $i$ and $t$, and time effects by $t . \mu$ is a constant, $\mathbf{x}_{i t}$ is a matrix containing demographic information for employee $i$ at time $t$ as well as information concerning the workplace $j$ to which the worker $i$ is linked. Although $\beta$ and $\eta$ can be fixed or random, we assume they are fixed in our estimations. All other effects are random. Personal heterogeneity $\left(\theta_{i}\right)$ is a measure of unobserved $\left(\alpha_{i}\right)$ and observed $\left(\mathbf{u}_{i} \boldsymbol{\eta}\right)$ human capital and follows the worker from firm to firm. Employer heterogeneity $\left(\psi_{j}\right)$ is a measure of firm-specific compensation policies and is paid to all workers of the same firm ${ }^{5} . \epsilon_{i t}$ is the statistical residual.

\footnotetext{
${ }^{5}$ Firm unobserved heterogeneity in productivity is a common factor in many models of wage dispersion, see Mortensen (2003).
} 
In full matrix notation, we have

$$
y=X \beta+U \eta+D \alpha+F \psi+\epsilon
$$

where: $y$ is the $N^{*} \times 1$ vector of earnings outcomes; $X$ is the $N^{*} \times q$ matrix of observable time-varying characteristics including the intercept; $\beta$ is a $q \times 1$ parameter vector; $U$ is the $N^{*} \times p$ matrix of time invariant person characteristics; $\eta$ is a $p \times 1$ parameter vector; $D$ is the $N^{*} \times N$ design matrix of the unobserved component for the person effect; $\alpha$ is the $N \times 1$ vector of person effects; $F$ is the $N^{*} \times J$ design matrix of the firm effects; $\psi$ is the $J \times 1$ vector of pure firm effects; and $\epsilon$ is the $N^{*} \times 1$ vector of residuals.

Estimation of (1) on large-scale data sets has been achieved by Abowd, Kramarz, and Margolis (1999) while treating firm and person effects as fixed. Here we focus on a mixed-model specification for wage determination because the sampling frame does not follow workers moving from firm to firm. When this is the case, parametric assumptions embedded in the mixed model are necessary to distinguish firm and individual unobserved heterogeneity. Therefore, identification of individual and firm random effects comes from the longitudinal and linked aspects of the data as well as from distributional assumptions. For individual effects, identification comes from the repeated observations on each individual over time. Identification of firm effects comes from repeated observations on workers from the same firm. Note that this also precludes the inclusion of worker-firm match effects. Our choice for a mixed specification is done without loss of generality since it can be shown that the least squares estimates of the fixed effects are a special case of the mixed model estimates (see Abowd and Kramarz (1999a)). 
We thus assume $\alpha$ and $\psi$ to be distributed normally :

$$
\left[\begin{array}{l}
\alpha \\
\psi \\
\epsilon
\end{array}\right] \sim N\left(\left[\begin{array}{l}
0 \\
0 \\
0
\end{array}\right],\left[\begin{array}{ccc}
\sigma_{\alpha}^{2} I_{N} & 0 & 0 \\
0 & \sigma_{\psi}^{2} I_{J} & 0 \\
0 & 0 & \Lambda
\end{array}\right]\right)
$$

where

$$
\Lambda=\left[\begin{array}{ccccc}
\Sigma_{1} & 0 & \ldots & & 0 \\
\ldots & \ldots & & & \ldots \\
0 & \ldots & \Sigma_{i} & \ldots & 0 \\
\ldots & & & \ldots & \ldots \\
0 & & \ldots & 0 & \Sigma_{N}
\end{array}\right]
$$

and

$$
\Sigma_{i}=V\left(\epsilon_{i}\right)
$$

\section{Estimation}

Parameters estimates are obtained in two steps. We first use Restricted Maximum Likelihood (REML) methods to get parameter estimates for the variance components in (4). We then solve the mixed equations to get estimates for the other parameters in the full model (3). We discuss each of these steps in turn.

REML methods involve applying maximum likelihood (ML) to linear functions of $y$, i.e. $K^{\prime} y$ (McCulloch and Searle (2001)). Note that $K^{\prime}$ is specifically designed so that $K^{\prime} y$ contains none of the fixed effects ( $\beta$ and $\eta$ in our case) which are part of the model for $y$. Thus, REML is simply ML applied on $K^{\prime} y$ and can be interpreted as maximizing a marginal likelihood.

Each vector of $K$ is chosen so that $k^{\prime} y=0$ or $K^{\prime}\left[\begin{array}{ll}X & U\end{array}\right]=0$. With 
$y \sim N(X \beta+U \eta, V)$ it follows that

$$
K^{\prime} y \sim N\left(0, K^{\prime} V K\right)
$$

where $V=D D^{\prime} \sigma_{\alpha}^{2}+F F^{\prime} \sigma_{\psi}^{2}+\Lambda$ is the covariance of earnings implied by (4). The REML log-likelihood is therefore

$$
\log L_{R E M L}=-\frac{1}{2}\left(N^{*}-r\right) \log 2 \pi-\frac{1}{2} \log \left|K^{\prime} V K\right|-\frac{1}{2} y^{\prime} K\left(K^{\prime} V K\right)^{-1} K^{\prime} y
$$

There are two advantages of using REML. First, variance components are estimated without being affected by the fixed effects. This means that the variance estimates are invariant to the values of the fixed effects. Second, in estimating variance components with REML, degrees of freedom for the fixed effects are taken into account implicitly whereas with ML they are not ${ }^{6}$. Both methods have the same merits of being based on the maximum likelihood principle and parameter estimates inherit the consistency, efficiency, asymptotic normality and invariance properties that follow.

Maximization of the likelihood function (5), while providing us with estimates for the variance components in (4), will not yield estimates for the random and fixed effects. In a second step, we obtain estimates for the random and fixed effects using a set of equations developed by Henderson, Kempthorne, Searle, and Krosigk (1959). These equations have become known as Henderson's Mixed Model Equations (MME) and simultaneously yield the Best Linear Unbiased Estimates (BLUE) of the fixed effects and Best Linear Unbiased Predictors (BLUP) of the random effects for known values of the variance components and

\footnotetext{
${ }^{6}$ REML estimates are also invariant to whatever set of contrasts is chosen for $K^{\prime} y$ as long as $K^{\prime}$ is of full rank (Searle, Casella, and McCulloch (1992)).
} 
$\Lambda^{7}$. Define the matrix of variance components as

$$
\Omega=\left[\begin{array}{cc}
\sigma_{\alpha}^{2} I_{N} & 0 \\
0 & \sigma_{\psi}^{2} I_{J}
\end{array}\right]
$$

For the particular structure implied by (3) and (4), the MME are

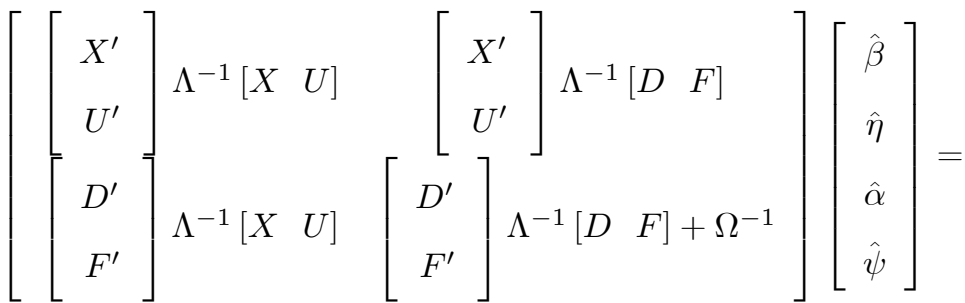

$$
\begin{aligned}
& \left.=\left[\begin{array}{c}
{\left[\begin{array}{c}
X^{\prime} \\
U^{\prime}
\end{array}\right] \Lambda^{-1} y} \\
D^{\prime} \\
F^{\prime}
\end{array}\right] \Lambda^{-1} y\right]
\end{aligned}
$$

Estimates for $\Lambda$ and $\Omega$ are obtained from the REML step.

Two important points should be made about the estimates for $(\hat{\beta}, \hat{\eta}, \hat{\alpha}, \hat{\psi})$. First, mixed model solutions $(\hat{\beta}, \hat{\eta}, \hat{\alpha}, \hat{\psi})$ converge to the least squares solutions as $|\Omega| \rightarrow \infty$ (if $\left.\Lambda=\sigma_{\epsilon}^{2} I_{N^{*}}\right)$. In this sense, the least squares solutions are a special case of the mixed model solutions. Second, unlike the usual random effects specification considered in the econometric literature, (3) and (4) do not assume that the random effects are orthogonal to the design ( $X$ and $U$ ) of the fixed effects $\left(\beta\right.$ and $\eta$ ), that is we do not assume $X^{\prime} D=X^{\prime} F=U^{\prime} D=U^{\prime} F=0$. If this were the case, we could solve for $\hat{\beta}$ and $\hat{\eta}$ independently of $\hat{\alpha}$ and $\hat{\psi}$.

\footnotetext{
${ }^{7}$ BLUE and BLUP estimates make us feel quite confident that a full information approach would not yield any better (in the sense of lower variance) estimator, although it might if we were to use a different class of estimators.
} 


\section{Data}

We use data from the 1999 and 2000 versions of the Workplace and Employee Survey (WES) conducted by Statistics Canada ${ }^{8}$. The survey is both longitudinal and linked in that it documents the characteristics of workers and workplaces over time ${ }^{9}$. The target population for the "workplace" component of the survey is defined as the collection of all Canadian establishments who paid employees in March of the year of the survey. The sample comes from the "Business registry" of Statistics Canada, which contains information on every business operating in Canada. The survey, however, does not cover the Yukon, the Northwest Territories and Nunavut. Firms operating in fisheries, agriculture and cattle farming are also excluded.

For the "employee" component, the target population is the collection of all employees working, or on paid leave, in the workplace target population. Employees are sampled from an employees list provided by the selected workplaces. For every workplace, a maximum number of 12 employees is selected and for establishments with less than 4 employees, all employees are sampled. In the case of total non-response, respondents are withdrawn entirely from the survey and sampling weights are recalculated in order to preserve representativeness of the sample. WES selects new employees and workplaces in odd years (at every third year for employees and at every fifth year for workplaces). Hence, the survey can only be representative of the whole target population during these re-sampling years.

We restrict our sample to employees who had the same employer in 1999 and 2000 and to those who have non-missing answers for our variables of interests. For the 1999 version of the survey, there are 23540 employee respondents. Of

\footnotetext{
${ }^{8}$ This is a restricted-access data set available in Statistics Canada Research Data Centers (RDC).

${ }^{9}$ Abowd and Kramarz (1999b) classify WES as a survey in which both the sample of workplaces and the sample of workers are cross-sectionally representative of the target population.
} 
this number, 18267 still had the same employer and responded in 2000. For workplaces, 5733 responded in 1999 and 5320 in $2000^{10}$.

To consider the effect of organizational design on pay, we restrict our sample further. This is necessary, as the questions on work practices are intended only for establishments with more than 10 employees and because there are some non-responses to these questions. The final sample size is then 19098 employees with 3771 workplaces in 1999 and 15048 employees and 3647 workplaces in 2000. Estimation results below are shown for the full sample and the sub-sample with information on organizational practices. Note that to control for the design effect in our estimations, we weighted our analyses with the final sampling weights for employees as recommended by Statistics Canada.

\subsection{Variables Used}

A complete list of variables used and descriptions is provided in the appendix. Note that our measure of computer use at work (CPU) excludes cash registers, sales terminals, scanners, manual typewriters and industrial vehicles or machines which are classified as "other technological devices (othtech)". Computercontrolled or computer-assisted technology like industrial robots, retail scanning systems, etc. are covered by variable CAT. We also have information on lifetime experience with a computer in a work environment (exp_cpu).

For the workplace's organizational practices, we have information on the use of various practices for non-managerial employees and for organizational changes during the years of the survey. While information on organizational change was collected in both years, information on organizational practices was collected only in 1999.

\footnotetext{
${ }^{10}$ For 1999 , we deleted the 586 non-responses from workplaces. We also removed a total of 745 workplaces in 2000 (these are the workplaces associated with the 2512 employees that were deleted from the 2000 sample.) The 2000 version of WES contains information on 20 779 employees. From this number, 2512 correspond to workers who stop being employed by a workplace in the sample or to workers linked to a workplace that did not respond in 2000 .
} 


\subsection{Descriptive Statistics}

Table 1 shows the probability of computer use at work for various demographic categories for in 1999. For example, approximately $60 \%$ of the Canadian workforce used a computer at work. Being female, not part of an union, and having a higher level of education are associated with higher computer usage. Among occupations, managers, clerks and professionals seem more likely to use a computer. Finally, workers in the "finance and insurance", "business services" or "information and cultural" sectors are also more likely to use a computer at work than those in other sectors. These patterns are similar to those provided by Autor, Katz, and Krueger (1998) for the U.S. and by DiNardo and Pischke (1997) for Germany ${ }^{11}$. Their summary statistics show that the probability of using a computer at work rises with the level of education both in the U.S. and in Germany. U.S. statistics suggest that female workers were more likely than male workers to use the computer while for Germany there is no clear difference between female and male workers.

Table 2 and 3 present descriptive statistics for all variables used in our analysis. It is not possible for confidentiality reasons to show minima and maxima. Turning first to the characteristics of the employees, our sample shows that $52.1 \%$ are females and that $56.6 \%$ are married. We include part-time employees and they represent $5.1 \%$ of our sample. Average seniority is close to 9 years and average lifetime work experience is close to 16 years. Around $39 \%$ of the employees are technician and almost $16 \%$ are professional while $14 \%$ are clerical workers.

Turning to workplaces, it is interesting to note that most of the workplaces operate in the retail $(30.2 \%)$ followed by transport (13.4\%). The most widely used workplace practice is information sharing with employees (49.6\%) followed

\footnotetext{
${ }^{11}$ See Table 1 in DiNardo and Pischke (1997).
} 
by suggestion, flexible job design and suggestion programs (both around 30\%). Finally, reengineering $(33.5 \%)$, rotation, integration and the implementation of total quality management programs were the organizational changes most likely to be experimented by the workplaces in our sample. In separate work, we look at correlations between individual workplace practices in order to verify if some practices were most likely to be used in conjunction with others. Since no correlation was above 0.5 , we decide in what follows to present results where each organizational practice enter separately (see also Black and Lynch (2001) who decide against using bundles of practices).

\section{Results}

Our main results are presented in Tables 5 to 7 . Table 5 presents estimates for a methodology and a set of explanatory variables similar to Krueger (1993). Columns 1 and 3 show Weighted Least Squares (WLS) estimates for a specification without a dummy for the use of a computer for 1999 and 2000, respectively, while we incorporate the impact of computer use in columns 2 and 4 . Table 6 presents estimated coefficients for a specification that includes experience with the computer, use of CAT or other technologies, seniority and firm size for pooled OLS (column 1), individual fixed effects (column 2) and mixed effects (column 3). Note that for the results in columns (1) and (2), our specification and methodology are similar to Entorf and Kramarz (1997) while column (3) shows coefficients obtained through our mixed model specification. Also, all regressions in Table 6 now include both industry ${ }^{12}$ and occupation ${ }^{13}$ dummies. Finally, Table 7 presents parameter estimates for organizational practices and

\footnotetext{
${ }^{12}$ Natural resources, labour tertiary, primary manufacturing, secondary manufacturing, capital tertiary, construction, transport, communication, retail, finance and insurance, real estate, business services, education and health care and information and culture.

${ }^{13}$ Manager, professional, technician/trades, sales/marketing, clerical/administrative and production without certificate.
} 
interactions with computer usage in the mixed effects model. We check the robustness of our results in Tables 8 and 9 . Table 8 shows the impact of including occupation and industry dummies on the estimated return to computer use. Table 9 presents coefficient estimates on the whole sample, i.e. including firms that were not asked about organizational practices.

\subsection{Returns to Computer Use}

From Table 5, we see that the cross-sectional computer wage premium is significant at around $21.6 \%$ and $21.9 \%$ in 1999 and 2000 respectively. If we include dummies for occupation (results not shown), returns to computer use drop slightly to about $18 \%$. These results are also very much in line with Krueger (1993) estimates (15 to 20\%). Focusing on column (4), we see that returns to education and experience are also significant at about $5 \%$ and $3 \%$ respectively. Surprisingly, being part of a union is associated with a wage gain of $14.2 \%$. In fact, taking into account computer use makes the return to being part of a union increase by about $3.6 \%^{14}$. Note that neither race nor working part-time have a significant impact on wages but being male and being married has a significant positive impact on wages. While these results are presented for comparison purposes with Krueger (1993), caution should be applied in the interpretation since we do not control for firm characteristics, occupations, unobserved human capital and unobserved firm heterogeneity.

\subsection{Controlling for Unobserved Ability}

Table 6 compares three specifications that include a similar set of explanatory variables as those used by Entorf and Kramarz (1997) and Entorf, Gollac, and Kramarz (1999). More specifically, we now include years of experience with a

\footnotetext{
${ }^{14}$ Union-nonunion wage differentials in WES are examined in details in Verma and Fang (2004).
} 
computer in a work environment, seniority, CAT use indicators as well as an indicator for the use of other technologies, industry and occupation dummies and controls for firm size. We compare pooled OLS results in column (1) to fixed individual effects (to control for unobserved ability) in column (2) and mixed effects (to control for firm unobserved heterogeneity) in column (3).

We find in column (1) that computer use is now associated with a wage premium of $10 \%$ while using CAT brings also brings a smaller wage gain. However, using other technologies generates a statistically significant negative return. Also, returns to computer experience are close to $1.3 \%$ per year. It is usual to find a lower return to computer use when controlling for computer experience.

In column (2), we find that taking into account individual unobserved ability brings the return to computer use to zero. Again, these results are similar to those obtained by Entorf and Kramarz (1997) who also controlled for unobserved human capital through fixed effects. Note that taking into account unobserved individual heterogeneity also lowers returns to schooling and seniority while returns to experience stay at around $1 \%$ per year. The firm-size wage premium also drops down for average and large size firms, consistent with the hypothesis that bigger firms employ more able worker. In general, coefficient estimates are somewhat imprecise in the fixed effects specification as can be seen by the size of the standard errors. This would presumably improve with a longer panel.

Column (3) shows estimates for the mixed-effects model of wage determination where we take into account both unobserved worker and workplace heterogeneity. Returns to computer use are about half what they were in the pooled OLS case but much higher than in the fixed effect specification. This seems to indicate that failure to take into account workplace unobserved heterogeneity will lead to biased estimates on the returns to computer use for reasons explained 
above. In fact, we do a likelihood ratio test of no firm unobserved heterogeneity and reject the null hypothesis quite strongly. The return to computer use experience also fell to $1 \%$. Using CAT is not associated with a significant wage premium, but using other technologies is still associated with a significant and negative return ${ }^{15}$.

These last results are different from Entorf, Gollac, and Kramarz (1999) in that we find evidence of a positive and statistically significant computer wage premium with methodologies controlling for both unobserved heterogeneity at the firm and worker level. These differences could be explained by higher computer returns in the late nineties or/and higher computer returns in North America as compared to Europe.

\subsection{Controlling for Organizational Practices}

In Table 7, we turn to the analysis of the impact of the organizational practices on wages, we find that increases in decentralization and downsizing lead to increased productivity (through wage gains) only when interacted with computer use. The same can be said for firms using flexible job design, information sharing and self-directed groups. This seems to indicate that in order to reap productivity gains from its investments in new technologies, a firm must emphasize decentralization and increase the autonomy of its workers. This is in contrast to the implementation of total quality management program, greater reliance on job rotation or firm inter-collaboration in $\mathrm{R} \& \mathrm{D}$ and production that lead to wage gains without the need of investment in new technologies. This is consistent with Bresnahan, Brynjolfsson, and Hitt (2002)'s findings using a completely different methodology.

\footnotetext{
${ }^{15}$ Remember that "other technologies" include mostly machines or technological devices that demand relatively low skill levels from labor, like cash registers and sales terminals scanners.
} 


\subsection{Robustness checks}

Table 8 provides some specification checks for the Pooled OLS and mixed models. It shows the impact of the inclusion of industry and occupation dummies. It can be seen that returns to computer use increase by about $3 \%$ when these controls are included. Returns to seniority, experience and schooling also increase somewhat.

In Table 9, we look at the impact of computer use for the full sample (remember that we restricted our sample earlier to the set of firms that were asked about their organizational practices (minimum 10 employees). Bringing back the smaller firms lowers the returns to computer use to about $3.9 \%$.

\section{Conclusion}

This paper presents a careful analysis of whether there exists a computer wage premium in Canada in 1999 and 2000 and whether this premium is related to the organizational practices of the firm, something that has never been done before. Our estimates suggest that a worker who uses the computer at work earns between $5-6 \%$ more than a nonuser. This result is robust to the use of a methodology that allows us to control for both firm unobserved heterogeneity and employee unobserved human capital.

Our results also suggest that some organizational practices (e.g. decentralization) lead to higher productivity gains when used simultaneously with information technologies. Furthermore, our mixed-effect methodology shows that there is a significant (both numerically and statistically) wage premium for computer use conditional on the use of no particular organizational practices. This suggests that wage gains from computer use can be higher if the "correct" choice of practices is made, but that these practices do not determine solely the 
existence of the computer-wage premium altogether. It reflects the fact that the work environment is modified as a result of the introduction of the technology and that workplace organization has to adapt to this new reality.

\section{References}

Abowd, J. M. and F. Kramarz (1999a). Econometric Analyses of Linked Employer-Employee Data. Labour Economics 6(1), 53-74.

Abowd, J. M. and F. Kramarz (1999b). The Analysis of Labor Markets using Matched Employer-Employee Data. In Handbook of Labor Economics, Volume 3B, pp. 2629-2710. Handbook in Economics, vol. 5. Amsterdam; New York and Oxford: Elsevier Science, North-Holland.

Abowd, J. M., F. Kramarz, and D. N. Margolis (1999). High Wage Workers and High Wage Firms. Econometrica 67(2), 251-333.

Anger, S. and J. Schwarze (2003). Does Future PC Use Determine Our Wages Today? Evidence from German Panel Data. Labour 17(3), 337-360.

Autor, D. H., L. F. Katz, and A. B. Krueger (1998). Computing Inequality: Have Computers Changed the Labor Market? Quarterly Journal of Economics 113(4), 1169-1213.

Bartel, A. P. and N. Sicherman (1999). Technological Change and Wages: an Interindustry Analysis. Journal of Political Economy 107(2), 285-325.

Berman, E., J. Bound, and Z. Griliches (1994). Changes in the Demand for Skilled Labor within U.S. Manufacturing: Evidence from the Annual Survey of Manufacturers. Quarterly Journal of Economics 109(2), 367-397.

Bertschek, I. and U. Kaiser (2004). Productivity Effects of Organizational Change: Microeconometric Evidence. Management Science 50(3), 394404. 
Black, S. E. and L. M. Lynch (2001). How to compete: The impact of workplace practices and information technology on productivity. Review of Economics and Statistics 82(1), 434-445.

Bresnahan, T. F., E. Brynjolfsson, and L. M. Hitt (2002). Information technology, workplace organization and the demand for skilled labor: Firm level evidence. Quarterly Journal of Economics 117(1), 339-376.

Bresnahan, T. F. and M. Trajtenberg (1995). General Purpose Technologies: "Engines of Growth"? Journal of Econometrics 117(1), 83-108.

Brynjolfsson, E. and L. M. Hitt (1995). Information technology as a factor of production: The role of differences among firms. Economics of Innovation and New technology 3(4), 183-200.

Brynjolfsson, E. and L. M. Hitt (2002). Intangible assets: Computers and organizational capital. Brookings Papers on Economic Activity: Macroeconomics 1, 137-199.

Brynjolfsson, E. and L. M. Hitt (2003). Computing productivity: Firm-level evidence. Review of Economics and Statistics 85(4), 793-808.

Chennells, L. and J. V. Reenen (2002). Technical Change and the Structure of Employment and Wages: A Survey of the Microeconometric Evidence. In Y. L. Nathalie Greenan and Jacques Mairesse (Eds.), Productivity, Inequality, and the Digital Economy: A Transatlantic Perspective. Cambridge, Massachusetts;London, England: The MIT Press.

DiNardo, J. E. and J.-S. Pischke (1997). The Returns to Computer Use Revisited: Have Pencils Changed the Wage Structure Too? Quarterly Journal of Economics 112(1), 291-303.

Dolton, P. and G. Makepeace (2004). Computer Use and Earnings in Britain. The Economic Journal 114(1), C117-C129. 
Doms, M., T. Dunne, and K. R. Trostke (1997). Workers, Wages and Technology. Quarterly Journal of Economics 112(1), 253-290.

Entorf, H., M. Gollac, and F. Kramarz (1999). New Technologies, Wages, and Workers Selection. Journal of Labor Economics 17(3), 464-491.

Entorf, H. and F. Kramarz (1997). Does Unmeasured Ability Explain the Higher Wages of New Technology Workers? European Economic Review 41, 1489-1509.

Gordon, R. J. (2004). Five Puzzles in the Behavior of Productivity, Investment, and Innovation. CEPR Discussion Paper No. 4414.

Henderson, C., O. Kempthorne, S. Searle, and C. Krosigk (1959). The Estimation of Environmental and Genetic Trend from Records Subject to Culling. Biometrics 15(2), 192-218.

Hitt, L. M. and E. Brynjolfsson (2002). Information Technology, Organizational Transformation, and Business Performance. In Y. L. Nathalie Greenan and Jacques Mairesse (Eds.), Productivity, Inequality, and the Digital Economy: A Transatlantic Perspective. Cambridge, Massachusetts;London, England: The MIT Press.

Krueger, A. B. (1993). How computers have changed the wage structure: Evidence from microdata. Quarterly Journal of Economics 108(1), 3360.

Lee, S.-H. and J. Kim (2004). Has Internet Changed the Wage Structure Too? Labour Economics 11(1), 119-128.

Levy, F. and R. J. Murname (2004). The New Division of Labor: How Computers are Creating the Next Job Market. Princeton and Oxford: Princeton University Press.

McCulloch, C. and S. Searle (2001). Generalized, Linear and Mixed Models. 
Wiley Series in Probability and Statistics, John Wiley and Sons Inc.

Mortensen, D. T. (2003). Wage Dispersion: Why Are Similar Workers Paid Differently? (Zeuthen Lectures). The MIT Press.

Searle, S. R., G. Casella, and C. McCulloch (1992). Variance Components. New York: John Wiley and Sons.

Verma, A. and T. Fang (2004). Union-nonunion wage differentials: Recent evidence from canadian workplaces. Working paper. 


\section{A Definition of variables used}

\section{A.1 Demographics}

Female Dummy variable equal to one if the individual is a women.

Married Dummy variable equal to one if the individual is married.

Kids Number of kids aged below six years old.

Black Dummy variable equal to one if the individual has black parents or grandparents.

Othraces Dummy variable equal to one if the individual has neither black nor white parents or grandparents.

\section{A.2 Human Capital}

Education Number of years of education.

Experience Number of years of experience.

\section{A.3 Job characteristics}

Wage Natural logarithm of the converted hourly wage.

Seniority Number of years of seniority.

\section{A.4 Technology}

CPU Dummy variable equal to one if the individual uses a computer at work.

CAD Dummy variable equal to one if the individual uses computer-assisted or computer-controlled technology like industrial robots, retail scanning systems at work. 
Otech Dummy variable equal to one if the individual uses cash registers, sales terminals, scanners, manual typewriters and industrial vehicles or machines at work.

Exp_cpu Years of lifetime experience with a computer.

\section{A.5 Changes in organizational practices}

Integration Dummy variable equal to one if the workplace experienced greater integration among different functional areas between April 1st and March 31st of the following year.

Centralization Dummy variable equal to one if the workplace experienced increase in the degree of centralization between April 1st and March 31st of the following year.

Downsizing Dummy variable equal to one if the workplace experienced downsizing (reducing the number of employees on payroll to reduce expenses; it is part of a reorganization in the workplace and not simply a response to a drop in demand) between April 1st and March 31st of the following year.

Decentralization Dummy variable equal to one if the workplace experienced a decrease in the degree of centralization between April 1st and March 31st of the following year.

Temporary Dummy variable equal to one if the workplace experienced greater reliance on temporary workers between April 1st and March 31st of the following year.

Part-time Dummy variable equal to one if the workplace experienced greater reliance on part-time workers between April 1st and March 31st of the following year. 
Re-engineering Dummy variable equal to one if the workplace experienced re-engineering (redesigning processes to improve performance and cost) between April 1st and March 31st of the following year.

Overtime Dummy variable equal to one if the workplace experienced increase in overtime hours between April 1st and March 31st of the following year.

Flexible Dummy variable equal to one if the workplace adopted flexible working hours between April 1st and March 31st of the following year.

Reduction Dummy variable equal to one if the workplace reduced the number of managerial levels between April 1st and March 31st of the following year.

Rotation Dummy variable equal to one if the workplace experienced greater reliance on job rotation and/or multi-skilling between April 1st and March 31st of the following year.

TQM Dummy variable equal to one if the workplace implemented total quality management between April 1st and March 31st of the following year.

External Dummy variable equal to one if the workplace experienced greater reliance on external suppliers of products/service (outsourcing) between April 1st and March 31st of the following year.

Collaboration Dummy variable equal to one if the workplace experienced greater inter-firm collaboration in R\&D, production or marketing between April 1st and March 31st of the following year.

Other Dummy variable equal to one if the workplace experienced other organizational changes between April 1st and March 31st of the following year. 


\section{A.6 Employee involvement practices}

Suggestion Dummy variable equal to one if an employee's suggestion program exist on a formal basis in the workplace. Includes employee survey feedback.

Flexible Dummy variable equal to one if a flexible job design program exist on a formal basis in the workplace. Includes job rotation, job enrichment/redesign (broadened job definitions), job enrichment (increased skills, variety or autonomy of work).

Information Dummy variable equal to one if an information sharing with employees program exist on a formal basis in the workplace. For example, with respect to firm's performance, colleagues' wages, technological or organizational changes, etc. This implies that employees have some feedback on policies.

Teams Dummy variable equal to one if problem solving teams exist on a formal basis in the workplace Responsibilities of teams are limited to specific areas such as quality or work flow (i.e. narrower range of responsibilities).

Committee Dummy variable equal to one if joint labour-management committees exist on a formal basis in the workplace. Include non-legislated joint labour-management committees and task teams that generally cover a broad range of issued, yet tend to be consultative in nature.

Workgroups Dummy variable equal to one if self-directed work groups exist on a formal basis in the workplace. Semi-autonomous work groups that have a high level of responsibility for a wide range of decisions/issues. 


\section{A.7 Firm characteristics}

Regions Regions are "Atlantic provinces", "Québec", "Ontario", "Alberta, Saskatchewan and Manitoba" and "British Columbia".

Tiny Dummy variable equal to one if the workplace has between 1 and 9 employees.

Small Dummy variable equal to one if the workplace has between 10 and 99 employees.

Medium Dummy variable equal to one if the workplace has between 100 and 499 employees.

Large Dummy variable equal to one if the workplace has more than 500 employees. 


\section{B Tables}


Table 1: Computer usage in 1999

\begin{tabular}{lr}
\hline \hline All workers & 60.1 \\
Men & 57.9 \\
Women & 63.5 \\
White & 60.9 \\
Black & 54.8 \\
Other & 60.7 \\
Union status & \\
Union member & 51.5 \\
Nonunion & 64.4 \\
Schooling & \\
Less than high school & 34.0 \\
High school & 52.1 \\
Some college & 65.0 \\
College & 66.5 \\
Post college & 83.7 \\
Occupations & \\
Manager & 81.9 \\
Professional & 84.7 \\
Technician/trades & 46.3 \\
Marketing/sales & 41.2 \\
Clerical/administrative & 84.8 \\
Production without certificate & 18.3 \\
Industries & \\
Forestry, mining, oil, and gas extraction & 54.9 \\
Primary product manufacturing & 49.6 \\
Secondary product manufacturing & 56.4 \\
Labour intensive tertiary manufacturing & 40.0 \\
Capital intensive tertiary manufacturing & 67.6 \\
Construction & 37.6 \\
Transportation, warehousing, wholesale & 65.5 \\
Communication and other utilities & 66.8 \\
Retail trade and consumer services & 47.2 \\
Finances and insurance & 93.9 \\
Real estate, rental and leasing operations & 65.9 \\
Education and health services & 63.5 \\
Information and cultural industries & 86.1 \\
Business services & 79.6 \\
Experience & \\
[0-10) years & 61.7 \\
[10-20) years & 58.4 \\
[20-30) years & 55.9 \\
[30 years and more & 59.0 \\
\hline \hline & \\
\hline &
\end{tabular}


Table 2: Descriptive statistics - Employees

\begin{tabular}{|c|c|c|}
\hline \multirow[b]{3}{*}{ Wage } & \multicolumn{2}{|c|}{1999} \\
\hline & Mean & Std Dev \\
\hline & 2.778 & 0.521 \\
\hline \multicolumn{3}{|l|}{ Highest completed degree } \\
\hline Less then high school & 0.107 & 0.309 \\
\hline High school & 0.175 & 0.380 \\
\hline Industry training & 0.053 & 0.162 \\
\hline Trade or vocational diploma & 0.088 & 0.283 \\
\hline Some college & 0.104 & 0.305 \\
\hline Completed college & 0.181 & 0.385 \\
\hline Some university & 0.077 & 0.266 \\
\hline Teacher's college & 0.002 & 0.049 \\
\hline University certificate & 0.018 & 0.132 \\
\hline Bachelor degree & 0.130 & 0.337 \\
\hline University certificate (> bachelor) & 0.019 & 0.135 \\
\hline Master's degree & 0.031 & 0.174 \\
\hline Degree in medicine, dentistry, etc. & 0.008 & 0.092 \\
\hline Earned doctorate & 0.006 & 0.078 \\
\hline Seniority & 8.517 & 8.206 \\
\hline Experience & 16.167 & 10.714 \\
\hline Black & 0.011 & 0.104 \\
\hline Other races & 0.280 & 0.449 \\
\hline Women & 0.521 & 0.500 \\
\hline Married & 0.566 & 0.496 \\
\hline $\mathrm{CPU}$ & 0.608 & 0.488 \\
\hline CAD & 0.120 & 0.325 \\
\hline Otech & 0.269 & 0.443 \\
\hline Exp_cpu & 5.865 & 6.373 \\
\hline Union & 0.279 & 0.449 \\
\hline Ptime & 0.051 & 0.220 \\
\hline \multicolumn{3}{|l|}{ Occupations } \\
\hline Manager & 0.151 & 0.358 \\
\hline Professional & 0.162 & 0.368 \\
\hline Technician & 0.390 & 0.488 \\
\hline Marketing/sales & 0.084 & 0.277 \\
\hline Clerical/administrative & 0.140 & 0.347 \\
\hline Production w/o certificate & 0.074 & 0.262 \\
\hline Number of employees: & \multicolumn{2}{|c|}{23540} \\
\hline
\end{tabular}


Table 3: Descriptive statistics - Workplaces

\begin{tabular}{lcc}
\hline \hline & \multicolumn{2}{c}{1999} \\
\cline { 2 - 3 } Industry & Mean & Std Dev. \\
\cline { 2 - 3 } Natural resources & 0.015 & 0.120 \\
Primary manufacturing & 0.025 & 0.156 \\
Secondary manufacturing & 0.030 & 0.170 \\
Labour tertiary & 0.045 & 0.208 \\
Capital tertiary & 0.048 & 0.214 \\
Construction & 0.053 & 0.223 \\
Transport & 0.134 & 0.340 \\
Communication & 0.022 & 0.146 \\
Retail & 0.302 & 0.459 \\
Finance and insurance & 0.069 & 0.253 \\
Real estate & 0.014 & 0.117 \\
Business services & 0.110 & 0.313 \\
Education and health services & 0.103 & 0.304 \\
Culture and information & 0.031 & 0.174 \\
Workplace size & \multicolumn{2}{c}{0.499} \\
Tiny & 0.461 & 0.498 \\
Small & 0.460 & 0.255 \\
Medium & 0.070 & 0.098 \\
\hline Large & 0.010 \\
\hline Number of workplaces: & \multicolumn{2}{c}{4072} \\
\hline \hline
\end{tabular}


Table 4: Descriptive statistics - Organizational practices

\begin{tabular}{lcc}
\hline \hline & \multicolumn{2}{c}{1999} \\
\cline { 2 - 3 } Organizational practices & & Sean \\
\cline { 2 - 3 } Suggestion & 0.303 & 0.460 \\
Flexible ind. & 0.308 & 0.462 \\
Info. Sharing & 0.496 & 0.500 \\
Problems solving & 0.256 & 0.437 \\
Committee & 0.197 & 0.398 \\
Self-directed groups & 0.103 & 0.305 \\
Organizational changes & & \\
Integration & 0.247 & 0.431 \\
Centralization & 0.127 & 0.333 \\
Downsizing & 0.131 & 0.338 \\
Decentralization & 0.075 & 0.264 \\
Temporary & 0.064 & 0.245 \\
Part-time change & 0.126 & 0.332 \\
Re-engineering & 0.335 & 0.472 \\
Overtime & 0.133 & 0.340 \\
Flexible & 0.201 & 0.401 \\
Hierarchy & 0.069 & 0.254 \\
Rotation & 0.253 & 0.435 \\
TQM & 0.205 & 0.404 \\
External & 0.158 & 0.364 \\
Collaboration & 0.186 & 0.389 \\
Other changes & 0.009 & 0.095 \\
\hline Number of workplaces: & \multicolumn{2}{c}{4072} \\
\hline \hline
\end{tabular}


Table 5: Impact of Computer Use in Basic Linear Models

\begin{tabular}{|c|c|c|}
\hline & \multicolumn{2}{|r|}{1999} \\
\hline & (1) & $(2)$ \\
\hline \multirow[t]{2}{*}{ Intercept } & $1.614^{* * *}$ & $1.666^{* * *}$ \\
\hline & $(0.032)$ & $(0.032)$ \\
\hline \multirow[t]{2}{*}{$\mathrm{CPU}$} & & $0.216^{* * *}$ \\
\hline & & $(0.015)$ \\
\hline \multirow[t]{2}{*}{ Union } & $0.153^{* * *}$ & $0.183^{* * *}$ \\
\hline & $(0.014)$ & $(0.014)$ \\
\hline \multirow[t]{2}{*}{ Education } & $0.052^{* * *}$ & $0.042^{* * *}$ \\
\hline & $(0.002)$ & $(0.002)$ \\
\hline \multirow[t]{2}{*}{ Exp. } & $0.029 * * *$ & $0.025^{* * *}$ \\
\hline & $(0.002)$ & $(0.002)$ \\
\hline \multirow[t]{2}{*}{ Exp. ^2 / 100} & $-0.046^{* * *}$ & $-0.038^{* * *}$ \\
\hline & $(0.006)$ & $(0.006)$ \\
\hline \multirow[t]{2}{*}{ Black } & -0.063 & -0.049 \\
\hline & $(0.077)$ & $(0.068)$ \\
\hline \multirow[t]{2}{*}{ Othraces } & $-0.027 * *$ & -0.022 \\
\hline & $(0.014)$ & $(0.014)$ \\
\hline \multirow[t]{2}{*}{ Ptime } & $-0.076^{* * *}$ & -0.034 \\
\hline & $(0.028)$ & $(0.028)$ \\
\hline \multirow[t]{2}{*}{ Female } & $-0.162^{* * *}$ & $-0.176^{* * *}$ \\
\hline & $(0.020)$ & $(0.020)$ \\
\hline \multirow[t]{2}{*}{ Married } & $0.163^{* * *}$ & $0.157^{* * *}$ \\
\hline & $(0.020)$ & $(0.019)$ \\
\hline \multirow[t]{2}{*}{ Married*Female } & $-0.044^{*}$ & $-0.042^{* *}$ \\
\hline & $(0.026)$ & $(0.026)$ \\
\hline R-squared & 0.318 & 0.353 \\
\hline Sample size & & 23540 \\
\hline
\end{tabular}


Table 6: Impact of Computer Use in OLS, Fixed- and Mixed-Effects Models

\begin{tabular}{|c|c|c|c|}
\hline & $\begin{array}{l}\text { Pooled OLS } \\
\text { (1) }\end{array}$ & $\begin{array}{c}\text { Fixed effect } \\
(2)\end{array}$ & $\begin{array}{c}\text { Mixed effects } \\
(3)\end{array}$ \\
\hline \multirow[t]{2}{*}{ Year } & $0.023^{* *}$ & -0.046 & $0.019^{* * *}$ \\
\hline & $(0.009)$ & $(0.060)$ & $(0.002)$ \\
\hline \multirow[t]{2}{*}{ Intercept } & $1.876^{* * *}$ & 1.402 & $2.017^{* * *}$ \\
\hline & $(0.042)$ & (1.085) & $(0.025)$ \\
\hline \multirow[t]{2}{*}{$\mathrm{CPU}$} & $0.095 * * *$ & -0.002 & $0.047^{* * *}$ \\
\hline & $(0.042)$ & $(0.040)$ & $(0.006)$ \\
\hline \multirow[t]{2}{*}{ CAT } & $0.026^{* * *}$ & -0.004 & -0.011 \\
\hline & (0.013) & $(0.017)$ & (0.005) \\
\hline \multirow[t]{2}{*}{ Othtech } & $-0.033^{* * *}$ & -0.067 & $-0.013^{* * *}$ \\
\hline & $(0.011)$ & $(0.015)$ & $(0.004)$ \\
\hline \multirow[t]{2}{*}{ Exp_cpu } & $0.013^{* * *}$ & 0.002 & $0.010^{* * *}$ \\
\hline & $(0.002)$ & (0.005) & $(0.001)$ \\
\hline \multirow[t]{2}{*}{ Exp_cpu ^2/100 } & $-0.026^{* * *}$ & -0.000 & $-0.018 * * *$ \\
\hline & $(0.010)$ & $(0.019)$ & $(0.004)$ \\
\hline \multirow[t]{2}{*}{ Education } & $0.022^{* * *}$ & 0.004 & $0.024^{* * *}$ \\
\hline & (0.001) & $(0.011)$ & (0.002) \\
\hline \multirow[t]{2}{*}{ Exp. } & $0.015^{* * *}$ & 0.090 & $0.015^{* * *}$ \\
\hline & $(0.002)$ & $(0.066)$ & $(0.001)$ \\
\hline \multirow[t]{2}{*}{ Exp. ${ }^{\wedge} 2 / 100$} & $-0.024 * * *$ & -0.016 & $-0.024^{* * *}$ \\
\hline & (0.005) & $(0.039)$ & $(0.002)$ \\
\hline \multirow[t]{2}{*}{ Seniority } & $0.007 * * *$ & $-0.010^{* *}$ & 0.000 \\
\hline & $(0.002)$ & $(0.005)$ & $(0.001)$ \\
\hline \multirow[t]{2}{*}{ Seniority ^ $2 / 100$} & $-0.009^{* *}$ & 0.012 & 0.005 \\
\hline & $(0.006)$ & $(0.030)$ & (0.003) \\
\hline \multirow[t]{2}{*}{ Black } & -0.029 & & $-0.052^{*}$ \\
\hline & $(0.043)$ & & $(0.027)$ \\
\hline \multirow[t]{2}{*}{ Othraces } & $-0.022^{* *}$ & & $-0.020^{* * *}$ \\
\hline & (0.009) & & $(0.006)$ \\
\hline
\end{tabular}


Table 6: Cont'd

\begin{tabular}{|c|c|c|c|}
\hline & $\begin{array}{c}\text { Pooled OLS } \\
\text { (1) }\end{array}$ & $\begin{array}{c}\text { Fixed effect } \\
(2)\end{array}$ & $\begin{array}{c}\text { Mixed effects } \\
(3)\end{array}$ \\
\hline Female & $\begin{array}{l}-0.101^{* * *} \\
(0.016)\end{array}$ & & $\begin{array}{l}-0.106^{* * *} \\
(0.008)\end{array}$ \\
\hline Married & $\begin{array}{c}0.093^{* * *} \\
(0.013)\end{array}$ & $\begin{array}{r}0.039 \\
(0.038)\end{array}$ & $\begin{array}{c}0.072^{* * *} \\
(0.006)\end{array}$ \\
\hline Married*Female & $\begin{array}{l}-0.038^{* *} \\
(0.018)\end{array}$ & $\begin{array}{r}-0.028 \\
(0.056)\end{array}$ & $\begin{array}{l}-0.037^{* * *} \\
(0.009)\end{array}$ \\
\hline Part-time & $\begin{array}{r}0.029 \\
(0.023)\end{array}$ & $\begin{array}{r}-0.033 \\
(0.048)\end{array}$ & $\begin{array}{l}-0.031^{* * *} \\
(0.009)\end{array}$ \\
\hline Union & $\begin{array}{l}0.067^{* * *} \\
(0.011)\end{array}$ & $\begin{array}{c}0.163^{* *} \\
(0.081)\end{array}$ & $\begin{array}{c}0.081^{* * *} \\
(0.006)\end{array}$ \\
\hline Small size & $\begin{array}{l}0.045^{* * *} \\
(0.017)\end{array}$ & $\begin{array}{c}0.045^{* *} \\
(0.022)\end{array}$ & $\begin{array}{c}0.054^{* * *} \\
(0.008)\end{array}$ \\
\hline Average size & $\begin{array}{l}0.149 * * * \\
(0.017)\end{array}$ & $\begin{array}{c}0.079 * * * \\
(0.026)\end{array}$ & $\begin{array}{l}0.118^{* * *} \\
(0.010)\end{array}$ \\
\hline Large size & $\begin{array}{c}0.206^{* * *} \\
(0.018)\end{array}$ & $\begin{array}{c}0.110^{* * *} \\
(0.029)\end{array}$ & $\begin{array}{c}0.184^{* * *} \\
(0.012)\end{array}$ \\
\hline Occupation dummies & Yes & Yes & Yes \\
\hline Industry dummies & Yes & Yes & Yes \\
\hline R-squared & 0.525 & & \\
\hline Sample size & 34146 & 34146 & 34146 \\
\hline
\end{tabular}

Statistical significance: ${ }^{*}=10 \% ;{ }^{* *}=5 \% ;{ }^{* * *}=1 \%$.

Robust standard errors in parentheses. 
Table 7: Coefficients on Disaggregated Organizational Practices

\begin{tabular}{|c|c|c|c|}
\hline \multirow[b]{2}{*}{ Integration } & \multicolumn{3}{|c|}{ Mixed Model } \\
\hline & $\begin{array}{r}0.005 \\
(0.007)\end{array}$ & $\times \mathrm{CPU}$ & $\begin{array}{r}-0.005 \\
(0.009)\end{array}$ \\
\hline Centralization & $\begin{array}{r}0.013 \\
(0.008)\end{array}$ & $\times \mathrm{CPU}$ & $\begin{array}{r}0.009 \\
(0.009)\end{array}$ \\
\hline Re-engineering & $\begin{array}{r}-0.001 \\
(0.006)\end{array}$ & $\times \mathrm{CPU}$ & $\begin{array}{r}-0.003 \\
(0.007)\end{array}$ \\
\hline Decentralization & $\begin{array}{l}-0.046^{* * *} \\
(0.009)\end{array}$ & $\times \mathrm{CPU}$ & $\begin{array}{l}0.049^{\text {*** }} \\
(0.010)\end{array}$ \\
\hline Reduction & $\begin{array}{l}-0.033^{* * *} \\
(0.009)\end{array}$ & $\times \mathrm{CPU}$ & $\begin{array}{r}0.005 \\
(0.011)\end{array}$ \\
\hline Downsizing & $\begin{array}{r}-0.006 \\
(0.008)\end{array}$ & $\times \mathrm{CPU}$ & $\begin{array}{c}0.019^{* *} \\
(0.009)\end{array}$ \\
\hline TQM & $\begin{array}{l}0.020^{* * *} \\
(0.007)\end{array}$ & $\times \mathrm{CPU}$ & $\begin{array}{r}-0.005 \\
(0.008)\end{array}$ \\
\hline Job rotation & $\begin{array}{c}0.013^{*} \\
(0.007)\end{array}$ & $\times \mathrm{CPU}$ & $\begin{array}{r}-0.010 \\
(0.008)\end{array}$ \\
\hline Flexible work hours & $\begin{array}{l}-0.020^{* *} \\
(0.008)\end{array}$ & $\times \mathrm{CPU}$ & $\begin{array}{r}0.013 \\
(0.009)\end{array}$ \\
\hline Collaboration & $\begin{array}{c}0.016^{* *} \\
(0.008)\end{array}$ & $\times \mathrm{CPU}$ & $\begin{array}{r}-0.014 \\
(0.009)\end{array}$ \\
\hline Outsourcing & $\begin{array}{r}0.006 \\
(0.008)\end{array}$ & $\times \mathrm{CPU}$ & $\begin{array}{r}-0.015 \\
(0.009)\end{array}$ \\
\hline Part time & $\begin{array}{r}-0.010 \\
(0.008)\end{array}$ & $\times \mathrm{CPU}$ & $\begin{array}{c}-0.016^{*} \\
(0.010)\end{array}$ \\
\hline Overtime & $\begin{array}{l}0.026^{* * *} \\
(0.008)\end{array}$ & $\times \mathrm{CPU}$ & $\begin{array}{r}-0.011 \\
(0.009)\end{array}$ \\
\hline Temporary work & $\begin{array}{r}-0.010 \\
(0.011)\end{array}$ & $\times \mathrm{CPU}$ & $\begin{array}{r}0.011 \\
(0.011)\end{array}$ \\
\hline Suggestion & $\begin{array}{c}0.024^{* *} \\
(0.011)\end{array}$ & $\times \mathrm{CPU}$ & $\begin{array}{l}-0.075^{* * *} \\
(0.011)\end{array}$ \\
\hline Flexible job design & $\begin{array}{l}-0.040^{* * *} \\
(0.013)\end{array}$ & $\times \mathrm{CPU}$ & $\begin{array}{l}0.036^{* * *} \\
(0.012)\end{array}$ \\
\hline Information sharing & $\begin{array}{c}0.003^{* *} \\
(0.012)\end{array}$ & $\times \mathrm{CPU}$ & $\begin{array}{c}0.025^{* *} \\
(0.011)\end{array}$ \\
\hline Problem solving & $\begin{array}{l}0.058^{* * *} \\
(0.012)\end{array}$ & $\times \mathrm{CPU}$ & $\begin{array}{l}-0.077^{* * *} \\
(0.011)\end{array}$ \\
\hline Self-directed groups & $\begin{array}{l}-0.007 \\
(0.015)\end{array}$ & $\times \mathrm{CPU}$ & $\begin{array}{l}0.062^{* * *} \\
(0.014)\end{array}$ \\
\hline Joint committee & $\begin{array}{r}0.011 \\
(0.012)\end{array}$ & $\times \mathrm{CPU}$ & $\begin{array}{r}0.007 \\
(0.011)\end{array}$ \\
\hline Other changes & $\begin{array}{l}-0.038^{* *} \\
(0.015)\end{array}$ & $\times \mathrm{CPU}$ & $\begin{array}{r}0.006 \\
(0.018)\end{array}$ \\
\hline
\end{tabular}

Statistical significance: ${ }^{*}=10 \% ;{ }^{* *}=5 \% ;{ }^{* * *}=1 \%$.

Robust standard errors in parentheses. 
Table 8: Robustness Check to Other Specifications

\begin{tabular}{lcccc}
\hline \hline & $(1)$ & $(2)$ & $(3)$ & $(4)$ \\
\hline Year & $0.021^{* *}$ & $0.022^{* *}$ & $0.017^{* * *}$ & $0.018^{* * *}$ \\
& $(0.001)$ & $(0.009)$ & $(0.002)$ & $(0.002)$ \\
Intercept & $1.731^{* * *}$ & $1.856^{* * *}$ & $1.947^{* * *}$ & $2.001^{* * *}$ \\
& $(0.032)$ & $(0.042)$ & $(0.019)$ & $(0.025)$ \\
CPU & $0.129^{* * *}$ & $0.094^{* * *}$ & $0.057^{* * *}$ & $0.047^{* * *}$ \\
& $(0.017)$ & $(0.011)$ & $(0.006)$ & $(0.006)$ \\
CAT & -0.022 & 0.023 & -0.002 & -0.001 \\
Othtech & $(0.017)$ & $(0.013)$ & $(0.005)$ & $(0.005)$ \\
& $-0.062^{* * *}$ & -0.032 & $-0.017^{* * *}$ & $-0.013^{* * *}$ \\
Exp_cpu & $(0.012)$ & $(0.011)$ & $(0.004)$ & $(0.004)$ \\
Exp_cpu ${ }^{*} 2 . / 100$ & $0.015^{* * *}$ & $0.012^{* * *}$ & $0.011^{* * *}$ & $0.009^{* * *}$ \\
& $(0.003)$ & $(0.002)$ & $(0.001)$ & $(0.001)$ \\
Education & $-0.034^{* *}$ & $-0.026^{* *}$ & $-0.021^{* * *}$ & $-0.018^{* * *}$ \\
& $(0.015)$ & $(0.010)$ & $(0.004)$ & $(0.004)$ \\
Exp. & $0.038^{* * *}$ & $0.022^{* * *}$ & $0.034^{* * *}$ & $0.024^{* * *}$ \\
& $(0.001)$ & $(0.001)$ & $(0.001)$ & $(0.001)$ \\
Exp. ${ }^{*} 2 . / 100$ & $0.022^{* * *}$ & $0.015^{* * *}$ & $0.020^{* * *}$ & $0.016^{* * *}$ \\
& $(0.002)$ & $(0.002)$ & $(0.001)$ & $(0.001)$ \\
\hline \hline & $-0.036^{* * *}$ & $-0.025^{* * *}$ & $-0.030^{* * *}$ & $-0.024^{* * *}$ \\
& $(0.005)$ & $(0.005)$ & $(0.002)$ & $(0.002)$ \\
\hline
\end{tabular}


Table 8: Cont'd

\begin{tabular}{|c|c|c|c|c|}
\hline & \multicolumn{2}{|c|}{ Pooled OLS } & \multicolumn{2}{|c|}{ Mixed effects } \\
\hline & (1) & $(2)$ & (3) & (4) \\
\hline \multirow{2}{*}{ Seniority } & $0.006^{* * *}$ & $0.007^{* * *}$ & -0.001 & 0.000 \\
\hline & $(0.002)$ & $(0.002)$ & $(0.001)$ & $(0.001)$ \\
\hline \multirow{2}{*}{ Seniority ^2/100 } & $-0.013^{* * *}$ & -0.009 & $0.009^{* *}$ & 0.004 \\
\hline & $(0.006)$ & $(0.006)$ & $(0.004)$ & $(0.003)$ \\
\hline \multirow{2}{*}{ Black } & -0.061 & -0.034 & $-0.080 * * *$ & $-0.052^{*}$ \\
\hline & $(0.046)$ & $(0.043)$ & $(0.029)$ & $(0.027)$ \\
\hline \multirow[t]{2}{*}{ Othraces } & $-0.034^{* * *}$ & $-0.022^{* *}$ & $-0.030 * * *$ & $-0.020 * * *$ \\
\hline & $(0.011)$ & $(0.009)$ & $(0.006)$ & $(0.006)$ \\
\hline \multirow{2}{*}{ Female } & $-0.171^{* * *}$ & $-0.101^{* * *}$ & $-0.154^{* * *}$ & $-0.107^{* * *}$ \\
\hline & $(0.015)$ & $(0.016)$ & $(0.008)$ & $(0.008)$ \\
\hline \multirow{2}{*}{ Married } & $0.138^{* * *}$ & $0.093^{* * *}$ & $0.090^{* * *}$ & $0.073^{* * *}$ \\
\hline & $(0.015)$ & $(0.013)$ & $(0.007)$ & $(0.006)$ \\
\hline \multirow[t]{2}{*}{ Married*Female } & $-0.066^{* * *}$ & $-0.038^{* *}$ & $-0.050 * * *$ & $-0.037 * * *$ \\
\hline & $(0.020)$ & $(0.018)$ & $(0.010)$ & $(0.009)$ \\
\hline \multirow[t]{2}{*}{ Ptimes } & -0.042 & 0.028 & $-0.042^{* * *}$ & $-0.029 * * *$ \\
\hline & $(0.029)$ & $(0.023)$ & $(0.009)$ & $(0.009)$ \\
\hline \multirow[t]{2}{*}{ Union } & $0.047^{* * *}$ & $0.063^{* * *}$ & $-0.053^{* * *}$ & $0.079 * * *$ \\
\hline & $(0.011)$ & $(0.011)$ & $(0.006)$ & $(0.006)$ \\
\hline \multirow[t]{2}{*}{ Small size } & -0.023 & $0.039 * *$ & $0.043^{* * *}$ & $0.053^{* * *}$ \\
\hline & $(0.019)$ & $(0.017)$ & $(0.009)$ & $(0.008)$ \\
\hline \multirow[t]{2}{*}{ Average size } & $0.145^{* * *}$ & $0.138^{* * *}$ & $0.107^{* * *}$ & $0.113^{* * *}$ \\
\hline & $(0.019)$ & $(0.017)$ & $(0.010)$ & $(0.010)$ \\
\hline \multirow[t]{2}{*}{ Large size } & $0.245^{* * *}$ & $0.188^{* * *}$ & $0.179^{* * *}$ & $0.174^{* * *}$ \\
\hline & $(0.021)$ & $(0.019)$ & $(0.012)$ & $(0.012)$ \\
\hline Occupation dummies & No & Yes & No & Yes \\
\hline Industry dummies & No & Yes & No & Yes \\
\hline R-squared & 0.407 & & & \\
\hline Sample size & 34146 & 34146 & 34146 & 34146 \\
\hline
\end{tabular}

Statistical significance: ${ }^{*}=10 \% ;{ }^{* *}=5 \% ;{ }^{* * *}=1 \%$.

Robust standard errors in parentheses. 
Table 9: Robustness Check to Sample Selection

\begin{tabular}{|c|c|c|c|}
\hline & $\begin{array}{c}\text { Pooled OLS } \\
(1)\end{array}$ & $\begin{array}{c}\text { Fixed effect } \\
(2)\end{array}$ & $\begin{array}{c}\text { Mixed effects } \\
\text { (3) }\end{array}$ \\
\hline \multirow[t]{2}{*}{ Year } & $0.024^{* * *}$ & -0.021 & $0.017^{* * *}$ \\
\hline & $(0.008)$ & $(0.044)$ & $(0.002)$ \\
\hline \multirow[t]{2}{*}{ Intercept } & $1.845^{* * *}$ & $1.850^{* *}$ & $1.943^{* * *}$ \\
\hline & $(0.037)$ & $(0.802)$ & $(0.023)$ \\
\hline \multirow[t]{2}{*}{$\mathrm{CPU}$} & $0.084^{* * *}$ & -0.009 & $0.039 * * *$ \\
\hline & $(0.013)$ & $(0.032)$ & $(0.005)$ \\
\hline \multirow[t]{2}{*}{ CAT } & $0.012^{*}$ & 0.002 & 0.003 \\
\hline & $(0.012)$ & $(0.014)$ & $(0.004)$ \\
\hline \multirow[t]{2}{*}{ Othtech } & $-0.029 * * *$ & 0.003 & -0.005 \\
\hline & $(0.012)$ & $(0.013)$ & $(0.003)$ \\
\hline \multirow[t]{2}{*}{ Exp_cpu } & $0.012^{* * *}$ & 0.001 & $0.009^{* * *}$ \\
\hline & $(0.002)$ & $(0.004)$ & $(0.001)$ \\
\hline \multirow[t]{2}{*}{ Exp_cpu ^2 /100 } & $-0.026^{* * *}$ & -0.000 & $-0.020^{* * *}$ \\
\hline & $(0.009)$ & $(0.017)$ & $(0.004)$ \\
\hline \multirow[t]{2}{*}{ Education } & $0.025^{* * *}$ & -0.011 & $0.024^{* * *}$ \\
\hline & $(0.001)$ & $(0.011)$ & $(0.001)$ \\
\hline \multirow[t]{2}{*}{ Exp. } & $0.015^{* * *}$ & 0.068 & $0.017 * * *$ \\
\hline & $(0.002)$ & $(0.050)$ & $(0.001)$ \\
\hline \multirow[t]{2}{*}{ Exp. ^2 /100 } & $-0.025^{* * *}$ & -0.025 & $-0.026^{* * *}$ \\
\hline & $(0.004)$ & $(0.034)$ & $(0.002)$ \\
\hline \multirow[t]{2}{*}{ Seniority } & $0.008^{* * *}$ & -0.008 & $0.002^{* * *}$ \\
\hline & $(0.002)$ & $(0.005)$ & $(0.001)$ \\
\hline \multirow[t]{2}{*}{ Seniority^2 /100 } & $-0.011^{*}$ & 0.002 & -0.000 \\
\hline & $(0.006)$ & $(0.032)$ & $(0.003)$ \\
\hline \multirow[t]{2}{*}{ Black } & -0.015 & & $-0.047^{*}$ \\
\hline & $(0.038)$ & & $(0.026)$ \\
\hline \multirow[t]{2}{*}{ Othraces } & -0.008 & & $-0.017^{* * *}$ \\
\hline & $(0.009)$ & & $(0.006)$ \\
\hline
\end{tabular}

